\title{
32. ORGANIC GEOCHEMISTRY OF SEDIMENTS FROM THE MOUTH OF THE GULF OF CALIFORNIA, LEG 64, SITES 474 AND 4 46 $^{1}$
}

\author{
Bernd R. T. Simoneit, ${ }^{2}$ Institute of Geophysics and Planetary Physics, \\ University of California-Los Angeles, Los Angeles, California
}

\begin{abstract}
Diatomaceous mud and an organically-rich claystone from holes at Sites 474 and 476 at the mouth of the Gulf of California were analyzed by organic geochemical methods to characterize their organic matter. The lipids of all three samples are primarily marine autochthonous, with the exception of Sample 474-5-3, 105-107 cm, which also contains some vascular plant wax. Based on the lipid composition, the sediment was deposited mainly under oxic environmental conditions. The kerogens were aliphatic and autochthonous marine. Two lignite fragments were also analyzed, and the data indicate that they are driftwood that absorbed marine bitumen from the surrounding sediment during coalification.
\end{abstract}

\section{INTRODUCTION}

Sedimentation during the Pleistocene epoch off Cabo San Lucas reflects the influence of open ocean communication with the Pacific; it consists of diatomaceous mud (Curray et al., 1979). Samples from holes at Site 474 were chosen to compare similar diatomites from the central Gulf of California.

The deepest sediment in Hole 476 is an organic claystone just above the conglomerates of metamorphic cobble. This represents some of the earliest sediment (Pliocene) accumulated on the subsiding continental fault blocks of the proto-Gulf. The lithology is banded to thinly laminated, containing $7.5 \%$ organic carbon with quartz silt, sparse glauconite, and many blue-green algal threads. Pollen and fungal spores are rare. The depositional environment for this sequence is equivocal but must represent moderately shallow water (initially in the photic zone) in a semirestrictive setting, such as an offshore bank. Thus, it was of interest to determine if the data from the organic geochemical analyses of this sample support this environmental interpretation.

The bulk parameters of two wood fragments were also analyzed to assess their origin.

\section{METHODS}

The small core samples were dried in an oven at $105^{\circ} \mathrm{C}$ and extracted after $\mathrm{C}, \mathrm{H}, \mathrm{N}$ analysis (onboard) with toluene and methanol $(4: 1)$. The larger sample was freeze dried and then extracted with methylene chloride and methanol (4:1) using ultrasonication. The extracts were concentrated on a rotary evaporator and treated with $\mathrm{BF}_{3}$ in methanol to derivatize free fatty acids. The extracts were then subjected to thin-layer chromatography (TLC) on silica gel, using methylene chloride as eluent. The bands (after development with iodine vapor) corresponding to hydrocarbons, esters, and ketones were scraped off the TLC plates and eluted with methylene chloride. The hydrocarbon and combined ester and ketone fractions were analyzed by gas chromatography (GC) and GC mass spectrometry (MS).

The GC analyses were carried out on a Hewlett-Packard 5830 gas chromatograph, using a $16 \mathrm{~m} \times 0.25 \mathrm{~mm}$ glass capillary column

\footnotetext{
${ }^{1}$ Curray, J. R., Moore, D. G., et al., Init. Repts. DSDP, 64: Washington (U.S. Govt. Printing Office.

2 Present address: School of Oceanography, Oregon State University, Corvallis, Oregon.
}

coated with OV-101 and programmed from 110 to $280^{\circ} \mathrm{C}$ at $4{ }^{\circ} \mathrm{C} / \mathrm{min}$. The carrier gas was $\mathrm{He}$ at a flow rate of $3 \mathrm{ml} / \mathrm{min}$.

A Finnigan 4000 quadrupole mass spectrometer interfaced directly to a Finnigan 9610 gas chromatograph and equipped with a $30 \mathrm{~m} \times$ $0.25 \mathrm{~mm}$ glass capillary column coated with SE-54 was used for the GC/MS analyses. The GC conditions for the GC/MS analyses were the same as those used for the analytical GC system. The mass spectrometric data was acquired and processed with a Finnigan-Incos 2300 data system.

The residual organic matter (i.e., kerogen) was separated by demineralization, using 40 to $60 \%$ hydrofluoric acid according to the method described by Stuermer et al., (1978). The University of California (Berkeley) Department of Chemistry Microanalytical Laboratory performed the elemental analyses. The methods described by Kaplan et al. (1970) and the Chicago PDB as a reference standard were used for the stable carbon isotope analyses.

\section{RESULTS AND DISCUSSION}

Table 1 presents the results of the carbon, lipid, and kerogen analyses. The lipid content is high and consists of predominantly polar material. Figure 1 indicates the distribution of various homologous compound series in the lipids.

\section{Samples from Site 474}

The $n$-alkanes of Samples 474-5-3, 105-107 cm and 474-6-5, 32-34 cm exhibit bimodal distributions, with maxima at $\mathrm{C}_{16}$ and $\mathrm{C}_{18}$ in the lower carbon number range and at $\mathrm{C}_{25}$ and $\mathrm{C}_{27}$ in the higher range (overall $\mathrm{CPI}=1.12$ and 1.11 , respectively; Fig. $1 \mathrm{~A}, \mathrm{~B})$. The source of the $n$-alkanes $>\mathrm{C}_{25}$ with an odd carbon number predominance is vascular plant wax (Simoneit, 1975; in press a, b), especially for Sample 474-5-3, 105-107 cm. The distributions $<\mathrm{C}_{25}$, when coupled with the unresolved complex mixture (hump) of branched and cyclic hydrocarbons maximizing at the GC retention of $n-C_{19}$, indicate a degraded microbial origin (Simoneit, in press a, b). The predominance of $n$-hexadecane and $n$-octadecane (also $n$-eicosane) may reflect a microreducing environment, as, for example, anaerobic microbial degradation in individual diatoms deposited in the sediment (Simoneit, 1975, 1977). The pristane-to-phytane ratio is 1.6 for both samples; perylene, other pigments 
Table 1. Analytical results for lipids and kerogen, Holes 474, 474A, and 476.

\begin{tabular}{|c|c|c|c|c|c|c|c|c|c|c|c|c|c|c|c|c|c|}
\hline \multirow[b]{2}{*}{$\begin{array}{l}\text { Sample } \\
\text { (interval in } \mathrm{cm} \text { ) }\end{array}$} & \multirow{2}{*}{$\begin{array}{l}\text { Sub-bottom } \\
\text { Depth } \\
\text { (m) }\end{array}$} & \multicolumn{2}{|c|}{ Carbon } & \multirow[b]{2}{*}{$\begin{array}{c}\mathrm{CaCO}_{3} \\
(\%)\end{array}$} & \multirow[b]{2}{*}{$\mathrm{C} / \mathrm{N}$} & \multicolumn{2}{|c|}{ Lipids } & \multicolumn{3}{|c|}{ n-Alkanes } & \multirow[b]{2}{*}{$\mathrm{Pr} / \mathrm{Ph}$} & \multicolumn{3}{|c|}{$n$-Fatty acids } & \multicolumn{3}{|c|}{ Kerogen } \\
\hline & & $\begin{array}{l}\text { Total } \\
(\%)\end{array}$ & $\begin{array}{c}\text { Organic } \\
(\%)\end{array}$ & & & $\begin{array}{l}\text { Total } \\
(\mu g / g)\end{array}$ & $\begin{array}{c}\text { Entrapped } \\
(\mu \mathrm{g} / \mathrm{g})\end{array}$ & $(\mu g / g)$ & $\mathrm{CPI}^{\mathrm{a}}$ & Maximum $^{b}$ & & $(\mu \mathrm{g} / \mathrm{g})$ & $\mathrm{CPI}^{\mathrm{a}}$ & Maximum ${ }^{b}$ & $\mathrm{H} / \mathrm{C}$ & $\mathrm{N} / \mathrm{C}$ & $\delta^{13} \mathrm{C}\left(\%_{6}\right)^{\mathrm{c}}$ \\
\hline $474-5-3,105-107$ & 44.05 & 4.7 & 2.8 & 16 & 15 & 2600 & 2000 & 13 & 1.12 & $16,18,27$ & 1.6 & 4 & 4.7 & 16.22 & 1.39 & 0.055 & -21.3 \\
\hline $474-6-5,32-34$ & 46.32 & 1.5 & 1.1 & 3 & 12 & 270 & 440 & 10 & 1.11 & 18,25 & 1.6 & 2 & 5.0 & 16,22 & 1.54 & 0.050 & -21.1 \\
\hline $474 \mathrm{~A}-41-1,78-79$ & 534.8 & ND & ND & ND & - & ND & ND & ND & - & - & - & ND & - & - & 1.41 & 0.030 & -24.2 \\
\hline $476-2-2,22-23$ & 10.7 & ND & ND & ND & - & ND & ND & ND & - & - & - & ND & - & - & 1.17 & 0.013 & -23.6 \\
\hline $476-21, C C$ & 194.55 & 7.1 & 7.1 & 0 & 17 & 3400 & ND & 3 & 0.9 & 17 & 1.4 & 5 & 3.3 & 16,22 & 1.48 & 0.061 & -20.6 \\
\hline
\end{tabular}

Note: $\mathrm{ND}=$ not determined.

a Carbon preference index summed from $C_{10}$ to $C_{30}$.

$\mathrm{b}$ Dominant homolog is underscored.

c Stable carbon isotope content versus Chicago PDB standard.
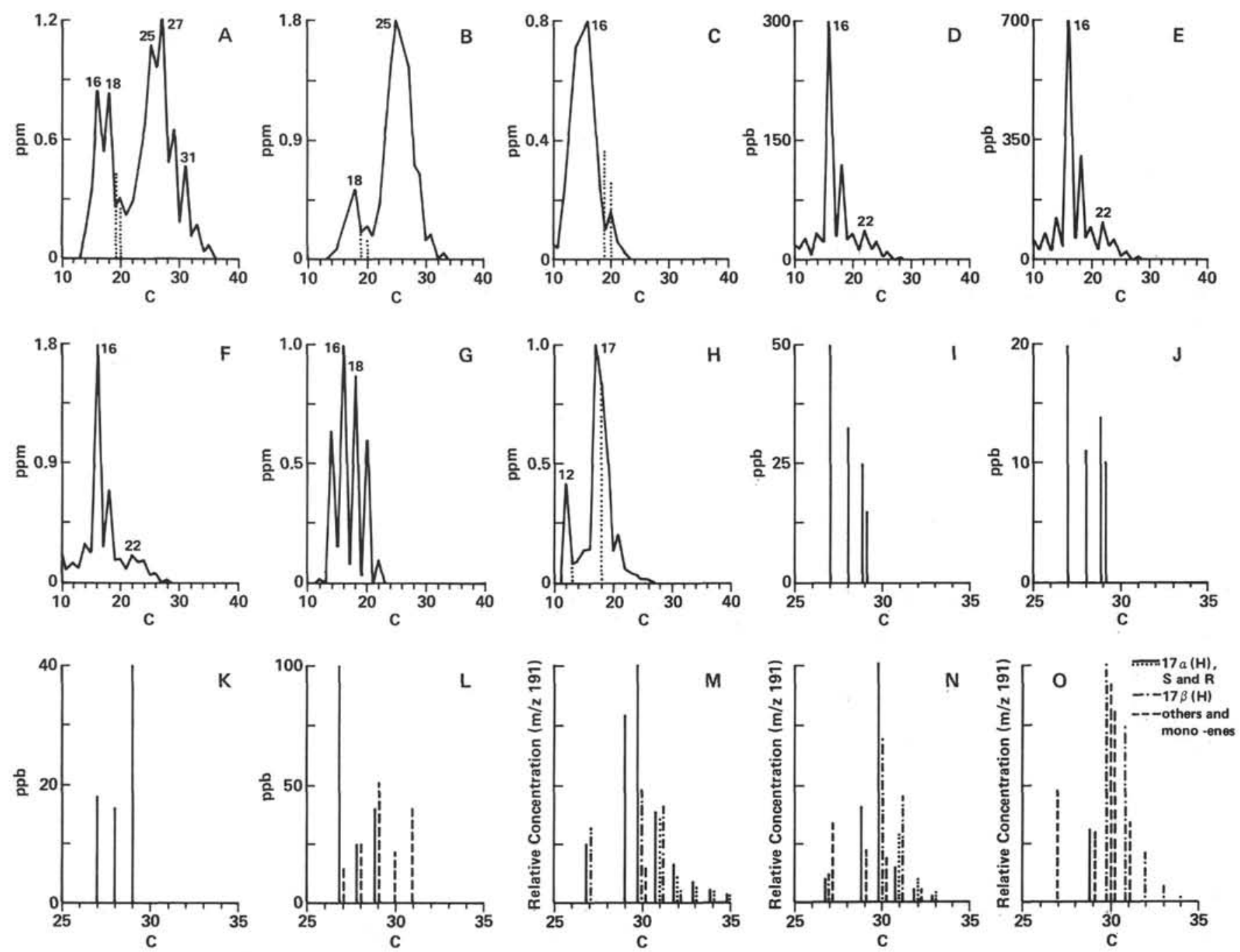

Figure 1. Concentrations versus carbon number of various lipid components from Holes 474 and 476 . ( $n$-alkanes [dotted line indicates isoprenoids], A. $474-5-3,105-107 \mathrm{~cm}$. B. 474-6-5, 32-34 cm. C. 476-21,CC. $n$-fatty acids, D. 474-5-3, $105-107 \mathrm{~cm}$. E. 474-6-5, 32-34 cm. F. 47621,CC. $n$-alkylcyclopentanes, G. 476-21,CC. $n$-alkan-2-ones [dotted line indicates isoprenoids], H. 476-21, CC. I. 474-5-3, 105-107 cm. J. 4746-5, 32-34 cm. K. 476-21,CC. ster-3-ones, L. 476-21,CC. triterpenoids, M. 474-5-3, 105-107 cm. N. 474-6-5, 32-34 cm. O. 476-21,CC.)

and sulfur could not be detected. This indicates that the overall environmental conditions of sedimentation were oxic and open marine (Didyk et al., 1979), which agrees with the lithologic description (Curray et al., 1979). The distribution of the $n$-fatty acids is unimodal (Fig. 1D and $\mathrm{E}$ ), ranging from $\mathrm{C}_{10}$ to $\mathrm{C}_{28}$, with a strong even-toodd carbon number predominance $(\mathrm{CPI}=4.7$ and 5.0, respectively) and a maximum at $n-\mathrm{C}_{16}$ (and a slight dom- inance of $n-\mathrm{C}_{22}$ ). These distributions indicate an autochthonous origin for this lipid fraction, again from microbial residues (Simoneit, 1975). No unsaturated fatty acids were detected. Dehydroabietic acid, the dominant molecular marker of resinous higher plants, was not detected (Simoneit, 1977). The ketones consist of primarily 6,10,14-trimethylpentadecan-2-one, which reflects an origin from phytol by microbial degradation. Ster-4- 
enes (Structure I) and minor amounts of steradienes occur in both samples. The distributions of the ster-4-enes (Fig. 1I and J) range from $\mathrm{C}_{27}$ to $\mathrm{C}_{29}$, with cholest-4-ene as the major homolog. The predominance of the $\mathrm{C}_{27}$ homolog may reflect a primarily marine autochthonous source of these markers (Huang and Meinschein, 1979). The triterpenoids range from $\mathrm{C}_{27}$ to $\mathrm{C}_{35}$ and consist mainly of the hopane series (II) with the $17 \alpha$ and $17 \beta$ stereochemistry and lesser amount of moretanes and hop17(21)-ene (III). Their relative concentrations (based on the $\mathrm{m} / \mathrm{z} 191$ peak intensity in the GC/MS data) are plotted in Figure $1 \mathrm{M}$ and N, respectively. The major homo$\log$ is $17 \alpha(\mathrm{H})$-hopane in both samples, and the $22 \mathrm{~S}$ to $22 \mathrm{R}$ stereomer ratio for the $\mathrm{C}_{31}-\mathrm{C}_{35} 17 \alpha(\mathrm{H})$ homologs is about 1.2 for Sample $474-6-5,32-34 \mathrm{~cm}$. These triterpenoids are probably autochthonous, and the dominance of the $17 \alpha(\mathrm{H})$ stereochemistry with the S/R of $\sim 1$ indicates geologic maturity, possibly by an unusually high geothermal gradient or recycled material (Dastillung and Albrecht, 1976; Simoneit and Kaplan, 1980).

The kerogens isolated from these samples are aliphatic where the $\mathrm{H} / \mathrm{C}$ ratios are about 1.4 and 1.5 and the N/C ratios are about 0.05 . These atomic ratios indicate an origin from microbial (mostly algal and bacterial) residues (Stuermer et al., 1978; Simoneit, in press $\mathrm{a}, \mathrm{b})$. The $\delta^{13} \mathrm{C}$ values for these kerogens are $-21.3 \%$ 。 for Section 474-5-3 and $-21.1 \%$ for Section $474-6-5$. The stable carbon isotope compositions fall within the range of marine organic matter (Kaplan, 1975).

Sample 474A-41-1, 78-79 $\mathrm{cm}$ consists of a lignite fragment with $\mathrm{H} / \mathrm{C}=1.41, \mathrm{~N} / \mathrm{C}=0.030$, and $\delta^{13} \mathrm{C}=$ $-24.2 \%$. Typical values for peat and vascular plant detritus are as follows: $\mathrm{H} / \mathrm{C}=1.0, \mathrm{~N} / \mathrm{C}=0.03-0.06$, and $\delta^{13} \mathrm{C}=-27$ to $-28 \%$ (Stuermer et al., 1978). Thus, the data for Sample 474A-41-1, 78-79 cm indicate a dilution of the terrigenous organic matter with more aliphatic and ${ }^{13} \mathrm{C}$-enriched material, which probably occurred in situ from the marine organic detritus during preservation and coalification.

\section{Samples from Site $\mathbf{4 7 6}$}

The $n$-alkanes of Section 476-21,CC (Fig. 1C) exhibit a unimodal distribution, ranging from $C_{10}$ to $C_{24}$ with a maximum at $n-\mathrm{C}_{16}$ and essentially no carbon number predominance $(\mathrm{CPI}=0.9)$. This distribution, and a narrow hump (maximum at GC retention of $n-C_{17}$ ), indicates an autochthonous origin from degraded microbial detritus, possibly blue-green algae and bacteria (Simoneit, 1975). Higher plant wax is not present. The pristane-to-phytane ratio is 1.4 , and no perylene, other pigment, or sulfur were detected. This indicates that the overall environmental conditions were oxic (Didyk et al., 1978), but because of the dominance of $n-C_{14}$, $n-\mathrm{C}_{16}$, there may have been reducing microenvironments to generate these even alkanes (Simoneit, 1977). The distribution of $n$-fatty acids (Fig. 1F) is essentially unimodal, ranging from $\mathrm{C}_{10}$ to $\mathrm{C}_{28}$, with a maximum at $\mathrm{C}_{16}$ (a minor predominance of $\mathrm{C}_{22}$ is also evident) and a strong even-to-odd carbon number predominance (CPI $=3.3$ ). This distribution indicates an origin from autochthonous microbial sources (Simoneit, 1975; in press a, b). No unsaturated fatty acids are detectable. Further possible microbial indicators are the alkylcyclopentanes (Fig. 1G), which may be reduction products from the corresponding fatty acids (even carbon-number predominance). The ketone fraction (Fig. 1H) consists of $n$-alkan-2-ones-ranging from $\mathrm{C}_{12}$ to $\mathrm{C}_{27}$, with maxima at $\mathrm{C}_{12}$ and $\mathrm{C}_{17}$ and essentially no carbon number predominance-and the isoprenoidal ketones 6,10 dimethylundecan-2-one and 6,10,14-trimethylpentadecan-2-one. These compounds are probably microbial degradation products from lipids and phytol (Simoneit, 1973; in press b).

No dehydroabietic acid was detected, and its absence indicates that no influx of resinous plant detritus occurred (Simoneit, 1977). There are traces of sesquiterpenoid residues, consisting of cadalene (IV) and probably cadinane (V). These compounds have an autochthonous algal origin (Simoneit, in press b). Ster-4-enes (I) and ster-3-ones (VI) occur in significant amounts (Fig. $1 \mathrm{~K}$ and $\mathrm{L}$, respectively). The range of ster-4-enes, from $\mathrm{C}_{27}$ to $\mathrm{C}_{29}$ and a maximum at $\mathrm{C}_{29}$, indicates a nonmarine distribution (Huang and Meinschein, 1979). The ster-3-ones range from $\mathrm{C}_{27}$ to $\mathrm{C}_{29}$ with a maximum at $\mathrm{C}_{27}$ (a marine distribution), and the 4-methylster-3-ones range from $\mathrm{C}_{27}$ to $\mathrm{C}_{31}$ with a maximum at $\mathrm{C}_{29}$. The 4-methylster-3-ones also indicate a source from microbiota (Bird et al., 1971), and thus the source of most of the steroidal markers is autochthonous marine. The triterpenoids (Fig. 1) predominantly consist of $17 \beta$ (H)-hopanes, moretanes, and hopenes. Hopane is the major homolog, and the series ranges to $\mathrm{C}_{34}$ with only the $22 \mathrm{~S}$ stereomer present $>\mathrm{C}_{31}$. The moretanes consist of the $\mathrm{C}_{27}, \mathrm{C}_{29}-\mathrm{C}_{31}$ homologs and hop-17(21)-ene (III) in the major olefin. The predominance of the $17 \beta(\mathrm{H})$ stereochemistry with the presence of the moretanes indicates a very immature lipid mixture (Dastillung and Albrecht, 1976; Simoneit and Kaplan, 1980; Simoneit et al., 1979). These triterpenoids are autochthonous and derived from the diagenesis of bacteriohopanepolyols and diploptene (Rohmer, 1975). Triterpenoidal acids are present and consist of the extended hopanoic acids (VII), ranging from $\mathrm{C}_{31}$ to $\mathrm{C}_{33}$ with the $17 \alpha(\mathrm{H})$ stereomers predominant over the $17 \beta(\mathrm{H})$. The major homolog is $17 \alpha(\mathrm{H})$-bishomohopanoic acid. A minor amount of bishomohop-17(21)-enoic acid (VIII) is also present. The source of these compounds is bacteriohopanepolyols (Rohmer, 1975).

The kerogen isolated from this sample is aliphatic, with an $\mathrm{H} / \mathrm{C}$ ratio of $1.48, \mathrm{~N} / \mathrm{C}$ ratio of 0.061 , and a $\delta^{13} \mathrm{C}$ value of $-20.6 \%$. The $\mathrm{H} / \mathrm{C}$ and $\mathrm{N} / \mathrm{C}$ indicate an origin from microbial residues (Stuermer et al., 1978; Simoneit, in press a, b), and the stable carbon isotope composition falls within the range of organic matter from marine sources (Kaplan, 1975).

Sample 476-2-2, 22-23 cm consists of a wood (lignite) fragment with $\mathrm{H} / \mathrm{C}=1.17, \mathrm{~N} / \mathrm{C}=0.013$, and $\delta^{13} \mathrm{C}=$ $-23.6 \%$. On comparison with the data typical for peat and vascular plant detritus $(\mathrm{H} / \mathrm{C}=1.0, \mathrm{~N} / \mathrm{C}=$ $0.03-0.06$, and $\delta^{13} \mathrm{C}=-27$ to $-28 \%$ [ [Stuermer et al., $1978]$ ), these values indicate a minor dilution of the ter- 
restrial organic matter with marine lipids during sedimentation.

\section{CONCLUSION}

The lipids of all three samples are of a primarily autochthonous marine origin from algae and bacteria. The only exception, Sample 474-5-3, 105-107 cm, also contains a significant higher plant wax component. None of the samples exhibit any influx of diterpenoids from resinous higher plants. Bulk geochemical data (e.g., $\mathrm{Pr} / \mathrm{Ph}$ ) indicate that the environmental conditions of sedimentation were oxic. Low-molecular weight even $n$-alkanes $\left(\mathrm{C}_{16}\right.$ and $\left.\mathrm{C}_{18}\right)$ indicate that some of the lipids were preserved in reducing microenvironments.

The kerogens of all three samples are primarily marine autochthonous. This is indicated by the aliphatic nature of their composition $(\mathrm{H} / \mathrm{C} \sim 1.5)$ and the stable carbon isotope data.

The data for the two lignite fragments indicate that they were driftwood that absorbed some of the surrounding sedimentary organic matter (e.g., bitumen) during in situ coalification.

\section{ACKNOWLEDGMENTS}

I thank D. Winter, B. Rohrback, and S. T. Lu for stable carbon isotope data; R. Philp for kerogen separations; E. Ruth for GC/MS data acquisition; D. Blumfield for technical assistance; and $\mathrm{M}$. Mazurek for reviewing the manuscript. Contribution 2057, Institute of Geophysics and Planetary Physics, UCLA.

\section{REFERENCES}

Bird, C. W., Lynch, J. M., Pirt, S. J., et al., 1971. Steroids and squalene in Methylococcus capsulatus grown on methane. Nature, 230:473-475.

Curray, J. R., Moore, D. G., Aguayo, J. E., et al., 1979. Leg 64 seeks evidence on development of basin in the Gulf of California. Geotimes 24:18-20.

Dastillung, M., and Albrecht, P., 1976. Molecular test for oil pollution in surface sediments. Mar. Pollut. Bull., 7:13-15.

Didyk, B. M., Simoneit, B. R. T., Brassell, S. C., et al., 1978. Geochemical indicators of palaeoenvironmental conditions of sedimentation. Nature, 272:216-222.

Huang, W.-Y., and Meinschein, W. G., 1979. Sterols as ecological indicators. Geochim. Cosmochim. Acta, 43:739-745.

Kaplan, I. R., 1975. Stable isotopes as a guide to biogeochemical processes. Proc. Roy. Soc. London, Ser. B, 189:183-211.

Kaplan, I. R., Smith, J. W., and Ruth, E., 1970. Carbon and sulfur concentration and isotopic composition in Apollo 11 lunar samples. Geochim. Cosmochim. Acta Suppl., 1:1317-1329.

Rohmer, M., 1975. Triterpenoides de procaryotes [Ph.D. dissert.]. L'Universite Louis Pasteur de Strasbourg, France.

Simoneit, B. R. T., 1973. Appendix I. Identification of isoprenoidal ketones in Deep Sea Drilling Project core samples and their geochemical significance. In Burns, R. E., Andrews, J. E., et al., Init. Repts. DSDP, 21: Washington (U.S. Govt. Printing Office), 909-923.
1975. Sources of organic matter in oceanic sediments [Ph.D. dissert.]. University of Bristol, England

1977. Diterpenoid compounds and other lipids in deep-sea sediments and their geochemical significance. Geochim. Cosmochim. Acta, 41:463-476.

in press a. Organic geochemistry of the shales and sapropels of the Cretaceous Atlantic. Proc. 8th Int. Meet. Org. Geochem., USSR Acad. Sci., Moscow.

in press b. The composition, sources and transport of organic matter to marine sediments-The organic geochemical approach. In Thompson, J. A. J. (Ed.), Proc. Symp. Mar. Chem. into the Eighties: Ottawa (Canada) (National Research Board).

Simoneit, B. R. T., and Kaplan, I. R., 1980. Triterpenoids as molecular markers of paleoseepage in Recent sediments of the Southern California Bight. Mar. Environ. Res., 3:113-128.

Simoneit, B. R. T., Mazurek, M. A., Brenner, S., et al., 1979. Organic geochemistry of Recent sediments from Guaymas Basin, Gulf of California. Deep-Sea Res., 26A:879-891.

Stuermer, D. H., Peters, K. E., and Kaplan, I. R., 1978. Source indicators of humic substances and protokerogen: Stable isotope ratios, elemental compositions and electron spin resonance spectra. Geochim. Cosmochim. Acta, 42:989-997.

\section{APPENDIX}

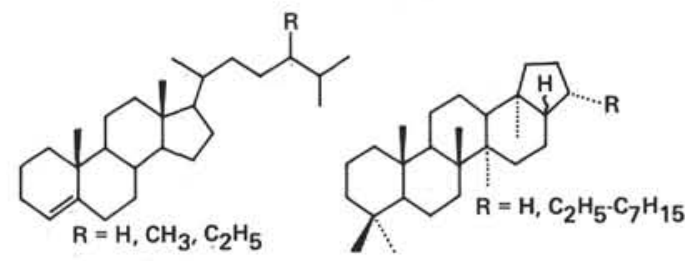

I. Ster-4enes

II. Hopanes
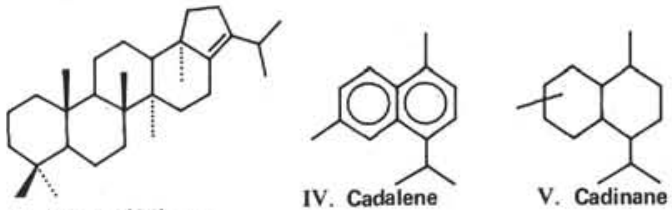

III. Hop-17(21)-ene

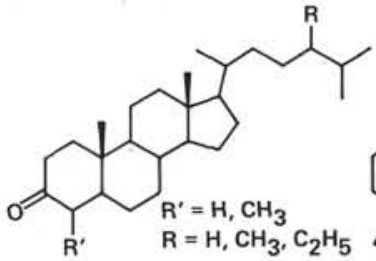

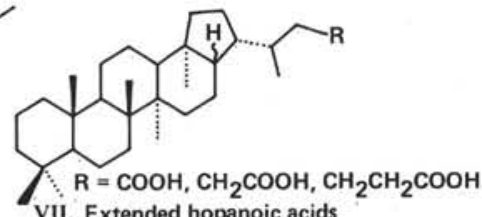

VI. Ster-3-ones

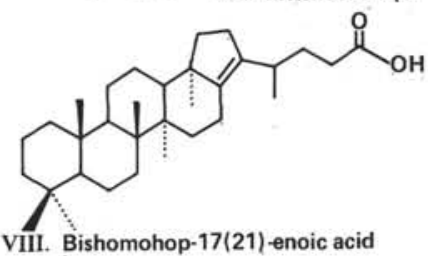

